\title{
Varenicline-Induced Manic Episode
}

\author{
Omer Gecici', Melike Nebioglu², Mukerrem Guven ${ }^{3}$
}

ÖZET:

Varenikline bag̃lı manik dönem

Vareniklin, nikotinik reseptörlerde kısmi agonist etki göstererek nikotin isteg̃ini bloke eden ve aşermeyi azaltan yeni bir antismoking (sigara içme karşıtı) ilaçtır. Psikiyatrik öyküsü olan hastalarda bazı önemli olumsuz psikiyatrik etkilerle ilișkilendirilir. Bugüne kadar, psikiyatrik öyküsü olmayan hastalarda varenikline bag̃lı manik dönem bildirilmemiștir. Bu yayında ilk kez, ailesinde ve kendisinde psikiyatrik hastalık öyküsü olmayan bir bireyde, varenikline bag̃lı psikotik bulgulu manik dönem tanımlanmaktadır.

Anahtar sözcükler: variniklin, mani, nikotin

Journal of Mood Disorders 2012;2(2):74-6

\begin{abstract}
:
Varenicline-induced manic episode

Varenicline is a novel antismoking agent that reduces cravings and blocks pleasure of nicotine by serving as a partial agonist to the nicotinic receptor. Varenicline has been associated with some important psychiatric adverse effects in patients with psychiatric history. However, varenicline related manic episode has not been reported so far in the literature in patients with no psychiatric history. Here we report a manic episode case with psychotic features developed in an individual on varenicline with no personal and family psychiatric history.
\end{abstract}

Key words: varenicline, mania, nicotine

Journal of Mood Disorders 2012;2(2):74-6
${ }^{1}$ Akdeniz University AMBAUM Dumlupinar Blv. Kampus 07070 Antalya-Turkey ${ }^{2}$ Haydarpasa Numune Eg. ve Arș. Hastanesi, Ruh Sagligi ve Hastalıkları Klinigi, istanbul-Turkey

Istanbul-Turkey
${ }^{3}$ Akdeniz University AMBAUM Dumlupinar Blv. Kampus, Antalya-Turkey

Yazıșma Adresi / Address reprint requests to: Mukerrem Guven, Akdeniz University AMBAUM Dumlupinar Blv. Kampus, Antalya-Turkey

Elektronik posta adresi / E-mail address: mukerremguven@gmail.com

Kabul tarihi / Date of acceptance: 16 Mayıs 2012 / May 16, 2012

Bag̃ıntı beyanı: 0.G., M.N., M.G.: Yazarlar bu makale ile ilgili olarak herhangi bir çıkar çatışmas bildirmemişlerdir.

Declaration of interest:

0.G., M.N., M.G.: The authors reported no conflict of interest related to this article.

\section{INTRODUCTION}

Nicotine dependence is probably one of the most prevalent conditions among dependency producing drugs, because nicotine is associated with the central nicotinic-cholinergic, dopaminergic, serotonergic, and gabaminergic pathways (1). Varenicline binds selectively with high affinity to alpha4beta2 neuronal nicotinic acetylcholine receptors. Its efficacy is the result of its activity at a subtype of the nicotinic acetylcholine receptor, where its binding produces agonist activity while simultaneously preventing nicotine binding to the alpha4beta2 receptors.

Agitation, aggression, and mood swings were reported as infrequent psychiatric adverse reactions in the studies conducted for the Food and Drug Administration (FDA) approval of varenicline (2). However, the FDA issued two recent Med Watch advisories regarding the reports of behavioral changes in patients taking varenicline. These behavioral changes have included erratic behavior, new onset of depressed mood, agitation, suicidal ideation, suicide attempts, and completed suicides within days to weeks of initiating varenicline. In addition FDA reported that not all the individuals affected from the varenicline had pre-existing histories of psychiatric illness (3). Some recently published studies reported that varenicline exacerbates the symptoms of schizophrenia (4), induces manic episode in bipolar disorder (2), and mixed mood and psychotic episodes in the patients with the past history of depression (5). However, varenicline related manic episode has not been reported in patients with no psychiatric history. To the best of our knowledge this is the first case report in the literature about onset of manic symptoms after initiating varenicline for smoking cessation in an individual with no personal and family psychiatric history. 


\section{CASE REPORT}

The 27-year-old female patient had her first psychiatric evaluation for showing signs of racing thoughts, increased speed and jumping from topic to topic in her speech, and increasingly labile mood during the week prior to presenting to the clinic.

She was reported to show markedly increased irritability, greatly decreased need for sleep, and displaying psychomotor activation. During the evaluation it was learned that a family physician prescribed varenicline according to the usual schedule $(0.5 \mathrm{mg} / \mathrm{d}$ initially, increasing to $2 \mathrm{mg} / \mathrm{d}$ over 1 week) to help her stop smoking about 3 weeks prior to her evaluation and she discontinued varenicline about 5 days prior to coming to the clinic.

The patient was seen at an outpatient psychiatric clinic at our hospital. Her speech was somewhat rapid and pressured. In addition to these she expressed some mystic statements. Moreover she had been in a continuous prayer. At this period her mood was upset and euphoric and her affect was distraught. Her thought processes were tangential with flight of ideas. She met criteria for a manic episode with psychotic features based on DSM IV criteria. Initially, she was administered $37.5 \mathrm{mg}$ long acting intramuscular form of risperidone. She was extremely aggressive and not accepting any other medications. She had no suicidal or homicidal ideations, intents, or plans. While she denied auditory or visual hallucinations, she had told her husband that she saw Prophet Muhammad, who told her "You would have very sacred skills."

Her insight and judgment were poor. She had no history of suicide attempts, no psychiatric disorders, and no family psychiatric history. The only medication she had recently taken was varenicline for smoking cessation. At admission her - Young Mania Scale score was 41.

Upon review of systems, the patient denied any physical symptoms of illness. Her vital signs were stable and her physical examination was normal and unremarkable, including a normal neurological examination. Laboratory data including complete blood count, kidney and liver function tests, and urinanalysis were all within normal limits. The working diagnoses were: Axis I: Bipolar disorder, mixed episode, severe, with psychotic features; Axis II: Deferred; Axis III: No active medical problems; Axis IV: Employment related problems; and Axis V: Global Assessment of Functioning score of 55.
At second visit, 15 days later the patient was much calmer. Her sleep was better than first admission. She was prescribed again $37.5 \mathrm{mg}$ long acting intramuscular form of risperidone. Upon next visit, she was much better, showed a fair amount of insight to her condition and asked appropriate questions about preventing this episode in the future. Her Young Mania Scale score was 20. We advised $25 \mathrm{mg}$ long acting intramuscular form of risperidone. At the fourth visit, the patient was well dressed and groomed. Her speech was normal in rate, tone, and latency. In addition, her thought processes were logical and linear. Her mood was "much better" and her affect was neutral. She denied any mystic delusions or hallucinations and had no suicidal or homicidal ideations, intents or plans. Her insight and judgment appeared fair. She continued to come for about 6 months for follow-up visits while she was not any medication. nontreatment period. She has had no recurrence of mood disturbance or psychosis during that period.

\section{DISCUSSION}

The onset of mania with psychotic features in this patient with no prior psychiatric history upon initiation of varenicline treatment for smoking cessation is suggestive of varenicline having the capacity to induce mania and psychosis. Though some cases has been reported in individuals with a documented psychiatric history $(2,4,5)$, to the best of our knowledge this is the first case in literature with no previous psychiatric history, who developed psychotic mania after exposure to varenicline.

During abstinence, varenicline stimulates low-level dopamine release by binding to alpha4beta2 receptors located on dopamine neurons (6). As a partial agonist, varenicline produces low to moderate levels of dopamine release, which reduces craving and withdrawal symptoms. This system is believed to be involved in the reinforcement and reward neuronal mechanism associated with smoking. Varenicline also binds with moderate affinity to the serotonin 5-HT3 receptors. The clinical trials assessing the efficacy and safety of varenicline have shown promising results (7-9).

By displacing nicotine from acetylcholine receptors, varenicline produces low to moderate levels of dopamine release and stimulates the central nervous mesolimbic dopamine system, this may upset the balance in 
cholinergic-adrenergic axis, which has been implicated in the physiology of mania. Its dopaminergic agonist action also has the potential to cause psychotic symptoms $(8,9)$.

Before the necessary kicking in period to see an effect of the applied medical treatment (long acting intramuscular form of risperidone), it was reported that the patient showed partial amelioration. This finding supports clinically that varenicline develops manic episode, as well.

The warnings from the FDA about the use of varenicline have been non-specific in terms of risk factors for adverse mood, psychotic, and agitation effects, and recommend caution with any history of mental illness (3). Some cases involving such adverse effects could be analyzed for the presence of both a family history of bipolar disorder and a personal history of depressive or bipolar disorder in their past. Some authors suggested to use drugs such as bupropion because of safety for smoking cessation in patients with mood disorder history (10). This case, who had developed manic symptoms upon starting varenicline for smoking cessation and had no personal and family psychiatric history, adds new information to the literature. Clinicians should be aware of the risk of inducing mood disorders with varenicline even patients have no personal and family psychiatric history.

This case highlights the need for clinicians to be aware of potential psychiatric adverse events with varenicline use. Further research is needed to more fully study varenicline safety, particularly among smokers with and without psychiatric history.

\section{References:}

1. Rosecrans JA: The biobehavioral effects of nicotine: interaction with brain neurochemical systems, in The Clinical Management of Nicotine Dependence. Edited by Cocores JA. New York, SpringerVerlag, 1991,pp 53-653.

2. Kohen I, Kremen N. Varenicline-induced manic episode in a patient with bipolar disorder. Am J Psychiatry. 2007;164:12691270.

3. Food and Drug Administration. FDA Med Watch Alert, Varenicline (marketed as Chantix): Information, February 1, 2008, and November 20, 2007. Available at www.fda.gov/cder/drug/ infopage/varenicline/default.htm. Accessed April 20, 2008.

4. Freedman R. Exacerbation of schizophrenia by varenicline [letter] Am J Psychiatry. 2007;164:1269.

5. Pumariega AJ, Nelson R, Rotenberg L, Varenicline-induced mixed mood and psychotic episode in a patient with a past history of depression. CNS Spectr. 2008;13(6):511-514. 7. Coe J, Brooks P, Vertelino M, et al. Varenicline: an $\alpha 4 \beta 2$ nicotinic receptor partial agonist for smoking cessation. J Med Chem. 2005;48:3474-3477.

6. Coe J, Brooks P, Vertelino M, et al. Varenicline: an $\alpha 4 \beta 2$ nicotinic receptor partial agonist for smoking cessation. J Med Chem. 2005;48:3474-3477.

7. Gonzales D, Rennard S, Nides M, et al. Varenicline, an $\alpha 4 \beta 2$ nicotinic acetylcholine receptor partial agonist, vs. sustainedrelease bupropion and placebo for smoking cessation: a randomized controlled trial. JAMA. 2006;296:47-55.

8. Jorenby DE, Hays JR, Rigotti NA, et al. Efficacy of varenicline, an $\alpha 4 \beta 2$ nicotinic acetylcholine receptor partial agonist, vs. placebo or sustained-release bupropion for smoking cessation: a randomized controlled trial. JAMA. 2006;296:56-63.

9. Tonstad S, Tonnesen P, Hajek P, et al. Effect of maintenance therapy with varenicline on smoking cessation: a randomized controlled trial. JAMA. 2006;296:64-71.

10. Fadi Alhatem, MD and James E. Black, MD, PhD. VareniclineInduced Mania in a Bipolar Patient. Clin Neuropharm 2009;32: 117-118. 